\title{
Epidural analgesia in obstetrics
}

\author{
Pros and cons for mother and baby
}

Were it not for nature's amnesia few people would question the need for effective relief of pain in labour. Epidural blockade is the only effective means of providing this relief; yet in the consumer's mind it seems often to be classed with other forms of obstetric intervention as an undesirable interference by the medical profession in what would otherwise be a trouble free and satisfying natural event.

The logic of such belief may seem unassailable: a lucky woman has a quick, easy labour with no intervention; her friend has a complicated labour with fetal distress, a drip, a lot of pain, epidural analgesia, and instrumental delivery - cause and effect are transposed and intervention is the culprit. Yet nature is not always kind, intervention may save life, and epidural analgesia has brought blessed relief to many mothers. After a few months, however, most do not remember the extreme pain that caused them to request epidural analgesia, and many are conditioned to feel dissatisfied with modern obstetric practice. In reality even caesarean section under epidural anaesthesia can be a most satisfying birth experience shared by both mother and father.

Nevertheless, even if we accept that satisfaction is strongly affected by conditioning and that epidural analgesia properly administered is the best means of relieving pain ${ }^{12}$ we still need to look carefully at the medical advantages for mother and baby. Let us take the mother first. The idea that amnesia is an adequate substitute for relief of pain was fashionable in the first half of this century with twilight sleep. This concept has recently made a comeback with the use of benzodiazepines in anaesthetic practice. But compassion and care for the subconscious dictate that a tolerable memory is better than one that is suppressed. Moreover, epidural analgesia prevents the adverse biochemical changes that may be associated with the stress of a painful labour and general anaesthesia. ${ }^{3-5}$ In appropriate doses it does not abolish the pain of placental abruption $^{6}$ or the imminent rupture of a uterine scar. ${ }^{78}$ Providing epidural analgesia in a complicated labour prepares the mother for intervention-emergency caesarean section, forceps delivery, or delivery of the aftercoming head or second twin ${ }^{9}$ - without recourse to general anaesthesia with its attendant risks. Epidural anaesthesia also avoids the delay in gastric emptying caused by systemic opioids. ${ }^{10} \mathrm{~A}$ patient with an epidural block can be made ready for emergency surgery remarkably quickly, ${ }^{11}$ unplanned awareness is avoided, and postoperative morbidity is less than if general anaesthesia is used. ${ }^{12}$

Epidural analgesia may be particularly valuable in patients with pre-eclampsia. It prevents the exacerbation of hypertension and the rise in noradrenaline concentration that may be associated with pain, ${ }^{13}$ producing instead beneficial haemodynamic changes. ${ }^{1+}$ Inserting the cannula may, however, carry a high risk in the presence of coagulopathy. ${ }^{15}$ Dangerous oversedation with epileptogenic major tranquillisers and opioids is avoided, and fits are less likely with good analgesia. ${ }^{16}$ By contrast, general anaesthesia may be hazardous, ${ }^{17}$ especially if there is laryngeal oedema. ${ }^{15} 18$

What are the disadvantages of epidural analgesia for the mother? An intravenous infusion is needed; dizziness occurs occasionally; postural hypotension and weakness of the legs make walking impossible in labour; and passing urine may be difficult. Shivering is a tiresome complication, though not serious, which can be helped by giving opioids epidurally. ${ }^{19}$ Impaired heat loss may cause maternal pyrexia. ${ }^{20}$ Epidural analgesia has no effect on the length of the first stage of labour, but prolongs the second, ${ }^{221}$ and an infusion of oxytocin may be required to make good a relative deficiency. ${ }^{22}$ Because mothers at high risk are overrepresented among those who have epidural analgesia the data may suggest that it "causes" abnormal delivery ${ }^{23}$; but with patience, ${ }^{2+25}$ modest doses, ${ }^{26}$ early topping up,,$^{27}$ and delayed expulsive efforts ${ }^{28}{ }^{29}$ most women have a normal delivery. With appropriate management introducing an epidural service need not increase the incidence of forceps deliveries. ${ }^{30}$

Analgesia may not always be perfect, ${ }^{26}{ }^{31}$ and a mother has a right to be resentful if it fails her. There is no place for the occasional epidural that is poorly conducted and inserted by an inadequately trained junior anaesthetist. In view of the severity of the headache and the occasional sixth nerve palsy that may follow accidental dural puncture the often quoted rate of $1 \%$ is unacceptable. With an appropriate technique it should be well below this, even in unskilled hands. ${ }^{32-3+}$

More serious sequelae are rare. Non-fatal accidental total spinal block was reported six times in one series of 27000 blocks, ${ }^{35}$ eight times in a national retrospective survey of about half a million blocks given in 1982-6 (D B Scott, Obstetric Anaesthetists' Association meeting, Oxford, 1988), and never in 14000 blocks given in one teaching hospital (personal observation). An epidural haematoma that requires evacuation may occur in women with coagulopathy ${ }^{15}$ and was reported once, and permanent paraplegia after injection of the wrong solution was also reported once in the national survey. Toxicity from accidental intravenous injection of the local anaesthetic occurred in three of the 27000 blocks $^{35}$ and in 20 
in the national survey. General anaesthesia was associated with 123 maternal deaths in England and Wales between 1970 and 1984, and epidural analgesia with nine. ${ }^{36-10}$ Four of these deaths were due to accidental total spinal block, which with appropriate resuscitation should not result in death or permanent damage. In short, permanent sequelae and fatal mishaps are very rare indeed and result from mistakes.

From the baby's point of view the benefits of maternal epidural analgesia are unequivocal. It is a pity that mothers consumed with doubts are not told this more often. Fetal acidosis resulting from poor placental exchange occurs only if severe hypotension arises and is allowed to persist. ${ }^{41}$ Otherwise, biochemical changes tend to be beneficial, ${ }^{3+2}$ with little deterioration during the second stage of labour, even if this is prolonged..$^{21+3}$ This may be partly because the maternal hyperventilation that may be provoked by pain and which negates the double Bohr effect does not occur, so oxygen exchange is well maintained. ${ }^{H}$ Furthermore, provided that maternal circulation is preserved by position and by preloading with crystalloids, intervillous blood flow is generally enhanced. ${ }^{45-48}$ The fetal circulation also improves. ${ }^{+950}$ Delivery is less traumatic, and neonatal retinal haemorrhages are observed less often. ${ }^{5152}$ The condition of the second twin at delivery is substantially better with maternal epidural analgesia, and the respiratory distress syndrome occurs less often. ${ }^{354}$

1 Morgan BM, Bulpitt CJ, Clifton P, Lewis PJ. The consumers' attitude to obstetric care. Br f Obstet Gynaecol 1984;91:624-8.

Robinson JO, Rosen M, Evans JM, Revill SI, David H, Rees GAD. Maternal opinion abou analgesia for labour. A controlled trial between epidural block and intramuscular pethidine combined with inhalation. Anuesthesia 1980;35:1173-81.

Thalme B, Belfrage P, Raabe N. Lumbar epidural analgesia in labour. 1. Acid-base balance and clinical condition of mother, fetus and newborn child. Acta Obstet Gynecol Scand 1974:53:27-35.

4 Falconer AD, Powles AB. Plasma noradrenaline levels during labour. Influence of elective lumbar epidural blockade. Anaesthesia 1982;37:416-20

5 Loughran PG, Moore J, Dundee JW. Maternal stress response associated with Caesarean delivery under general and epidural anaesthesia. Br f Obstet Gynuecol 1986;93:943-9.

6 Paterson MEL. The aetiology and outcome of abruptio placentae. Acta Obstel (jynecol Scand 1979;58:31-5.

7 Crawford JS. The epidural sieve and $\mathrm{MBC}$ (minimal blocking concentration): an hypothesis. Anaesthesia 1976:31:1277-80.

8 Amir $\mathbf{W}$, Peter $J$, Etan $Z$. Trial of labour without oxytocin in patients with a previous cesarean section. Am f Perinatol 1987:4:140-3.

9 Jaschevatzky $\mathrm{OE}$, Shalit $\mathrm{A}$, Levy $\mathrm{Y}$, Grunsein $S$. Epidural analgesia during labour and iwin pregnancy. Brf Obstel Gynaecol 1977;84:327-31.

10 Nimmo WS, Wilson J, Prescott LF. Narcotic analgesics and delayed gastric emptying during labour. Lancet 1975; $;$ : $890-3$.

11 Laishley RS, Morgan BM, Reynolds F. Effect of adrenaline on extradural anaesthesia and plasma bupivacaine concentrations during Caesarean section. Br f Anaesth 1988;60:180-6.

12 Morgan BM, Aulakh JM, Barker JP, Reginald PW, Goroszeniuk T, Trojanowski A. Anaesthetic morbidity following Caesarean section under epidural or general anaesthesia. Lancet 1984;i:32830.

13 Abboud T, Artal R, Sarkis F, Henriksen EH, Kammula RK. Sympathoadrenal activity, maternal, fetal and neonatal responses after epidural anesthesia in the preeclamptic patient. Am $\mathcal{F}$ Obstet Getal and neonatal respons.

14 Newsome LR, Bramwell RS, Curling PE. Severe preeclampsia: hemodvnamic effects of lumbar epidural anesthesia. Anesth Analg 1986;65:31-6.

15 Sibai BM, Taslimi MM, El-Nazer A, Amon E, Mabie BC, Ryan GM. Maternal-perinatal outcom associated with the syndrome of hemolysis, elevated liver enzymes and low platelets in severe preeclampsia-eclampsia. Am 7 Obstet Gynecol 1986;155:501-9.

16 Moir DD, Victor-Rodrigues L, Willocks J. Epidural analgesia during labour in patients with preeclampsia. Br f Obstet Gynaecol 1972;79:465-9.

17 Benedetti TJ, Benedetti JK, Stenchever MA. Severe preeclampsia-maternal and fetal outcome. Clin Exp Hypertens 1982;1:401-16.

18 Jouppila R, Jouppila P, Hollmen A. Laryngeal oedema as an obstetric anaesthesia complication. Acta Anaesthesiol Scand 1980;24:97-8.

19 Reynolds F. Extradural opioids in labour. Br f Anaesth (in press)

20 Fusi L, Steer PJ, Maresh MJA, Beard RW. Maternal pyrexia associated with the use of epidural analgesia in labour. Lancet $1989 ;: 1: 1250-2$

21 Studd JWW, Crawford JS, Duignan NM, Rowbotham CJF, Hughes AO. The effect of lumbar epidural analgesia on the rate of cervical dilatation and the outcome of labour of spontancous epidural analgesia on the rate of cervical dilatal
onset. Br f Obstet Gynaecol 1980;87:1015-21.

22 Walton P. Reynolds F. Epidural analgesia and instrumental deliverv. Anuesthesia 1984:39:218-23.

23 Goodfellow CF, Hull MGR, Swaab DF, Dogterom J, Buijs RM Oxytocin deficiency at delivery with epidural analgesia. Br 7 Obstet Gynaecol 1983;90:214-9.

24 Doughty A. Selective epidural analgesia and the forceps rate. Br f Anaesth 1969:41:1058-62.

25 Potter N, MacDonald RD. Obstetric consequences of epidural analgesia in nulliparous patients. Lancet 1971;i: 1031-4.

26 Thorburn J, Moir DD. Extradural analgesia: the influence of volume and concentration of bupivacaine on the mode of delivery, analgesic efficacy and motor block. Br f Anuesth 1981;53:933-9

27 Phillips KC, Thomas TA. Second stage of labour with or without extradural analgesia. Anaesthesio 1983;38:972-6.

28 McQueen J, Mylrea L. Lumbar epidural analgesia in labour. Br.Med f 1977:i:640.

29 Maresh M, Choong KH, Beard RW. Delayed pushing with lumbar epidural analgesia in labour. Brf Obstet Gynaecol 1983;90:623-7.

30 Bailey PW, Howard FA. Epidural analgesia and forceps delivery: laying a bogey. Anaesthesio 1983;38:282-5.

31 Morgan BM, Bulpit CJ, Clifton P, Lewis PJ. Analgesia and satisfaction in childbirth (The Queen Charlotte's 1000 mother survey). Lancet 1982;ii:808-10.

32 Doughty A. Inadvertent dural puncture-an avoidable accident. Anaesthesia 1979;34:116.
Babies do better in the neonatal period after maternal epidural block than after pethidine ${ }^{3}$ or general anaesthesia ${ }^{55}$ (though the neonatal effects of pethidine can be reversed by naloxone ${ }^{56}$ ). In a survey of 6442 births neonatal mortality was reduced with epidural analgesia, particularly for low birthweight babies. ${ }^{57}$ In two smaller series the perinatal mortality associated with twin deliveries ${ }^{53}$ and caesarean section ${ }^{55}$ was halved with epidural blockade, though the differences were not significant. Various neonatal neurobehavioural tests have been used in the search for more subtle effects. Babies whose mothers have received epidural bupivacaine are alert but have reduced $^{56}$ or increased ${ }^{58}$ muscle tone, and they may perform better than babies of untreated mothers. ${ }^{5960}$

In summary, epidural blocks may be beneficial to both mother and baby, particularly in high risk cases, but to avoid maternal complications they require time, skill, constant vigilance, and the continuous presence within the hospital of a trained anaesthetist. Consequently, they are not universally available. Moreover, with the constraints facing the health service an epidural service may become a luxury that few districts can afford.

FELICITY REYNOLDS

Reader in Pharmacology Applied to Anaesthesia,

St Thomas's Hospital,

London SE1 7EH

MacDonald $R$. Dr Doughty's technique for the location of the epidural space. Anaesthesia 1983;38:71-2

34 Reynolds F. Avoiding accidental dural puncture. Br $\mathcal{F}$ Anaesth 1988;61:515-6.

35 Crawford JS. Some maternal complications of epidural analgesia for labour Anaesthesia 1985 40:1219-25

36 Department of Health and Social Security. Reports on confidential enquiries into maternal deaths in England and Wales 1970-1972. London: HMSO, 1975. (Report on Health and Social Subjects 11.)

37 Department of Health and Social Security. Reports on confidential enquiries into maternal deaths in England and Wales 1973-1975. London: HMSO, 1979. (Report on Health and Social Subjects 14.)

38 Department of Health and Social Security. Reports on confidential enquiries into maternal deaths in England and Wales 1976-1978. London: HMSO, 1982. (Report on Health and Social Subjects 26.)

39 Department of Health and Social Security. Reports on confidential enquiries into maternal deaths in Fngland and Wales 1979-1981. London: HMSO, 1986. (Report on Health and Social Subjects 29.

40 Department of Health and Social Security. Reports on confidential enquiries into maternal deaths in England and Wales 1982-1984. London: HMSO, 1989. (Report on Health and Social Subject 34.

+1 Antoine C, Young BK. Fetal lactic acidosis with epidural anesthesia. Am $\mathcal{J}$ Obstet Gynecol 1982;142:55-9.

42 Pearson JF, Davies P. The effect of continuous lumbar epidural analgesia upon fetal acid-base status during the first stage of labour. Brf Obstet (jynaecol 1974;81:971-4.

43 Pearson JF, Davies $P$. The effect of continuous lumbar epidural analgesia upon fetal acid-base status during the second stage of labour. Br f Obstet Gynaecol 1974;81:975-9.

44 Swanstrom S, Bratteby LE. Metabolic effects of obstetric regional analgesia and asphyxia in the newborn infant during the first 2 hours after birth. III. Ajustment of arterial blood gases and acidbase balance. Acta Paediatr Scand 1981;70:811-8.

45 Huovinen K, Lehtovirta P, Forss M, Kivalo I, Teramo K. Changes in placental intervillous blood flow measured by the '"Xenon method during lumbar epidural block for elective Caesarean ection Acto Anuesth Scand 1979;23:529-33.

46 Hollmen AI, Jouppila R, Jouppila P, Koivula A, Vierola H. Effect of extradural analgesia using bupivacaine and 2-chloroprocaine on intervillous blood flow during normal labour. Br 7 Anaesth 1982:54:837-42

47 Jouppila P, Jouppila R, Hollmen A, Koivula A. Lumbar epidural analgesia to improve intervillou blood flow during labour in severe preeclampsia. Am F Obstet (iynecol 1982;59:158-61.

48 Giles WB, Lah FX, Trudinger BJ. The effect of epidural anaesthesia for Caesarean section on maternal uterine and fetal umbilical artery blood flow velocity wave forms. $\mathrm{Br} f \mathrm{Obstel} G y n a e c o l$ 1987;94:55-9.

49 Lindblad A, Bernow J, Marsal K. Obstetric analgesia and fetal aortic blood flow during labour. $\mathrm{Br} f$ Obstet Gynaecol 1987;94:306-11.

50 Lindblad A, Bernow J, Vernersson E, Marsal K. Effects of extradural anaesthesia on human fetal blood flow in utero. Comparison of three local anaesthetic solutions. Br f Anaesth 1987;59:1265-

51 Maltau JM, Egge K. Epidural analgesia and perinatal retinal haemorrhages. Acta Anaesthesiol Scand 1980;24:99-101.

52 Van Zundert A, Jansen J, Vaes $L$, Soetens $M$ de Vel $M$, Van Der AA P. Extradural analgesia and retinal haemorrhage in the new born. Br f Anaesth 1986;58:1017-21.

53 Weekes AR, Cheridjian VE, Mwanje DK. Lumbar epidural analgesia in twin pregnancy. Br Med $1977 ;$ ii: $730-2$

4 Crawford JS. A prospective study of 200 consecutive twin deliveries. Anaesthesia 1987;42:33-43.

5 Ong BY, Cohen MM, Palahniuk RJ. Anesthesia for Cesarean section - effects on neonates. Anest Analg 1989;68:270-5.

56 Wiener PC, Hogg MI, Rosen M. Neonatal respiration, feeding and neurobehavioural state. Effect of intrapartum bupivacaine, pethidine and pethidine reversed by naloxone. Anaesthesie 1979;34:996-1004.

57 David H, Rosen M. Perinatal mortality after epidural analgesia. Anaesthesia 1976;31:1054-9.

Rosenblatt DB, Belsey EM, Lieberman BA, et al. The influence of maternal analgesia on neonatal behaviour. II. Epidural bupivacaine. Br f Obstel Gynaecol 1981;88:407-13.

59 Kanto J, Erkkola R. Obstetric analgesia: pharmacokinetics and its relation to neonatal behavioural and adapive

60) Kangas-Saarela $T$, Jouppila R, Jouppila $P$, Hollmen A, Puukka $M$, Juujarvi $K$. The effect of segmental epidural analgesia on the neurobehavioural responses of newborn infants. Act Anaesthesiol Scand 1987;31:347-51. 